\title{
Concentrations of Catecholamines in the Median Eminence of the Sheep after Superovulation
}

\author{
B. PÁSTOROVÁ
}

Department of Anatomy, Histology and Physiology, Institute of Physiology, University of Veterinary Medicine, Košice, Slovak Republic

Received September 9, 2006

Accepted April 14, 2008

\begin{abstract}
Pástorová B.: Concentrations of Catecholamines in the Median Eminence of the Sheep after Superovulation. Acta Vet. Brno 2008, 77:159-162

The effect of hormonal superovulation preparations of FSH (450 IU) or PMSG (1500 IU), on concentration of catecholamines (dopamine, norepinephrine and epinephrine) was studied in the oestrus period using radioenzymatic methods in the median eminence of the sheep.

The administration of FSH caused a significant increase in the concentrations of norepinephrine (NE) and epinephrine (EPI) in the median eminence (ME) of sheep $(p<0.01$ and $p<0.05$, respectively). The comparison of the effect of hormonal preparations on the changes in catecholamine levels showed that the effect of FSH was observed mostly in eminentia mediana of sheep.

We propose that the given changes in concentrations of catecholamines in the median eminence of sheep after administration of PMSG or FSH are related to steroids after hormonal stimulation.
\end{abstract}

Ewes, brain, norepinephrine, dopamine, FSH and PMSG superovulation

The median eminence (ME) represents a small mildly convex protuberance situated in front of and behind the infundibulum (Rajtová and Kačmárik 1999); it forms the floor of the third ventricle. This site has more morphological features; numerous nerve pathways converge here and biologically active compounds and neurotransmitters accumulate. The $\mathrm{ME}$ is also considered as the terminal field where higher numbers of neurons from different cerebral regions terminate. The hormonal preparations generally used for inducing superovulation in farm animals act on steroidogenesis and influence hypothalamic nuclei and their gonadotropic receptors through a feedback mechanism (Deaver and Dailey 1983). High concentrations of circulating oestrogens affect adrenergic receptors and the levels and metabolism of catecholamines in the central and peripheral adrenergic system (FernandezPardal et al. 1986; Pástorová and Várady 1996ab). Simultaneously with changes in the metabolism of catecholamines, some changes in the activity of catecholamine-degrading enzymes in brain of sheep were observed after hormonal treatment (Chevillard et al. 1981; Pástorová and Várady 1996a). With regard to the sporadic information about the effect of hormonal preparations that are commonly used in the biotechnology of controlled reproduction on the catecholaminergic system in the median eminence of sheep, we studied changes in catecholamines after administration of FSH and PMSG.

\section{Materials and Methods}

Examinations were carried out using brain samples from 18 Slovak Merino sheep, 2 - 3 years old, of average body mass $42 \pm 3.8 \mathrm{~kg}$, in their oestrous period (September - October). The sheep were fed standard molasses feed with vitamin additives twice daily. The oestrus of all sheep was synchronized with intravaginal sponges $(20 \mathrm{mg}$ chlorsuperlutin). On day 13 after instillation, the sponges were removed and FSH ad usum vet. (FOLISTIMAN, Spofa, Prague) was administered i.m. to the first experimental group $(n=6)$ three times daily for 2 days at total doses of 450 IU. After complete synchronization of oestrus, the sheep of the second experimental group $(\mathrm{n}=6)$ were hormonally stimulated by the administration of 1500 IU PMSG (Bioveta, Ivanovice na Hané, Czech Republic) and the remaining 6

Address for correspondence:

Doc. RNDr. Bernadetta Pástorová, PhD.

Department of Physiology

University of Veterinary Medicine

Komenského 73, 04181 Košice, Slovak Republic

Phone: ++421915984773

Fax: ++421556323666

E-mail:klapacova@uvm.sk

http://www.vfu.cz/acta-vet/actavet.htm 
sheep served as control. The animals were slaughtered 104 - 110 hours after the first dose of FSH or PMSG. The project of the experiment was carried out by the Ethics Committee UVM Košice according to the Statute No. 289/2003.

The brains for radioenzymatic determination of catecholamines were rapidly removed, and samples were taken from the median eminence. Tissues were immersed into liquid nitrogen and stored in a frozen state until further processing. Samples for radioenzymatic determination of catecholamines were homogenized in microhomogenizers in cooled $\mathrm{HClO}_{4}\left(\mathrm{c}=0.4 \cdot \mathrm{mol}^{-1}\right)$ with an addition of $1 \mu \mathrm{l}$ reduced glutathione $\left(\mathrm{c}=0.05 \cdot \mathrm{mol}^{-1}\right)$ per 1 milligram of tissue, and they were centrifuged at $15000 \times g \cdot \mathrm{min}^{-1}$ at $0{ }^{\circ} \mathrm{C}$ for $30 \mathrm{~min}$. Catecholamines were determined by the radioenzymatic method according to Johnson et al. (1980) in $50 \mu \mathrm{l}$ of supernatants (in parallel samples). The radioactivity of catecholamine derivatives was measured using a scintillating spectrometer Packard-Tri-Carb in a ${ }^{3} \mathrm{H}$ channel. The results were expressed as catecholamine nmol. $\mathrm{mg}^{-1}$ protein. Proteins were determined in identical tissue according to Lowry et al. (1951). Due to the higher concentrations of catecholamines in the median eminence, the tissue supernatants were diluted with redistilled water in the ratio of $1: 20$. The coefficient of methodical variation calculated from 10 repetitions of one sample was $4.2 \%$ for norepinephrine and $4.1 \%$ for dopamine. The results were statistically evaluated by nonpaired $t$-test and are given as means \pm S.E.M.

\section{Results}

The obtained results are presented in Figs $1-3$. The administration of 450 IU FSH and 1500 IU PMSG caused no difference in the level of dopamine in comparison with the controls (Fig. 1). The levels of norepinephrine in the median eminence (Fig. 2) after the administration of FSH were considerably increased $(p<0.01)$. FSH stimulation resulted in a similar significant increase $(p<0.05)$ in the level of epinephrine (Fig 3). On the contrary, the administration of PMSG reduced the concentration of norepinephrine in the eminentia mediana of sheep $(p<0.01)$ whereas the contents of epinephrine were not altered in comparison with the control animals.

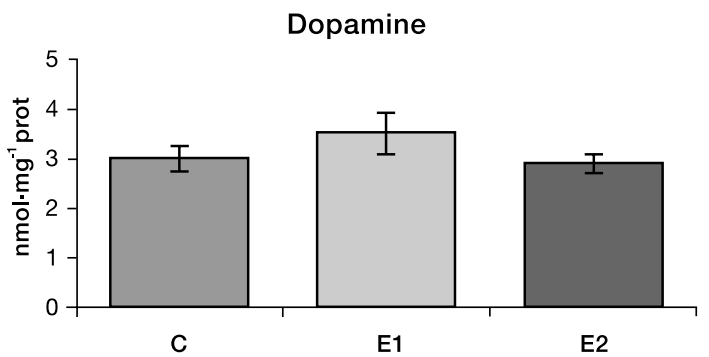

Fig 1. The effect of oestrus synchronization and hormonal stimulation by 450 IU FSH and 1500 IU PMSG on the dopamine levels in the median eminence. The results are expressed in $\mathrm{nmol} \cdot \mathrm{mg}^{-1}$ prot (means \pm S.E.M.).

$\mathrm{C}$ - control group with synchronized oestrus ( $20 \mathrm{mg}$ chlorsuperlutin)

E1 - group with synchronized oestrus and stimulated by administration of FSH (450 IU)

E2 - group with synchronized oestrus and stimulated by 1500 IU PMSG

Significant differences: $* p<0.05 ; * * p<0.01$

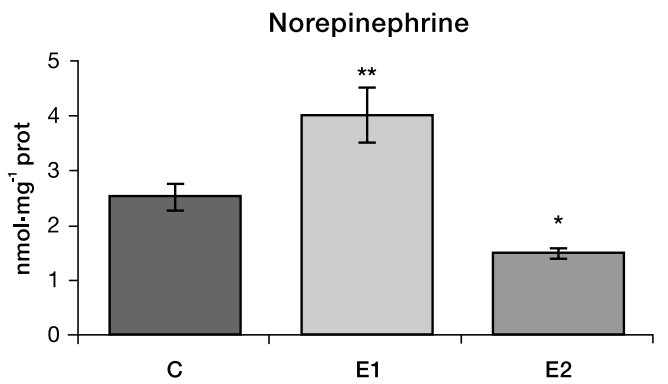

Fig 2. The effect of oestrus synchronization and hormonal stimulation by 450 IU FSH and 1500 IU PMSG on the norepinephrine levels in the median eminence.

Symbols as Fig 1. Significant differences: $* p<0.05 ; \quad * * p<0.01$ 


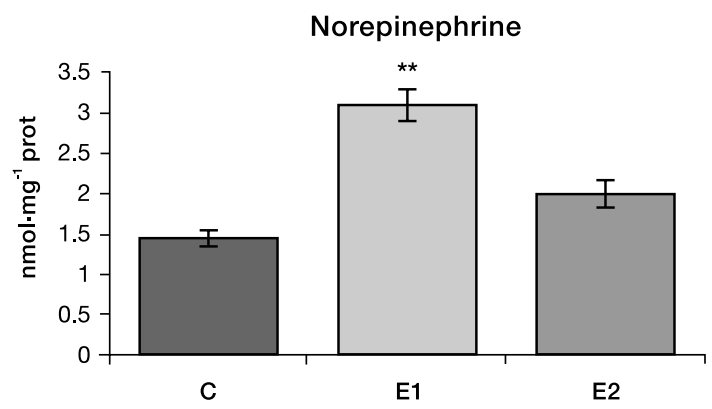

Fig 3. The effect of oestrus synchronization and hormonal stimulation by 450 IU FSH and 1500 IU PMSG on the epinephrine levels in the median eminence.

Symbols as Fig 1. Significant differences: $* * p<0.01$

\section{Discussion}

Administration of the pituitary hormone FSH is associated with luteolysis $48 \mathrm{~h}$ after its administration followed by polyovulation oestrus (Schiewe et al. 1991). Most authors (Moor et al. 1985; Schiewe et al. 1991; Driancourt and Fry 1992) prefer FSH preparations to serum gonadotropins (PMSG) in biotechnically directed reproduction because FSH is a better regulator of the superovulatory process. This ability is based on the short halflife of FSH in the organism and the more stable gonadotropic effect of FSH (Moor et al. 1985; Schiewe et al. 1991), although it has to be administered several times daily. The extrahypophyseal hormone PMSG, which shows LH and FSH activity, has a long half-life in the organism and its administration is accompanied with a marked increase of oestrogens in the blood plasma. High concentrations of circulating oestrogens recorded after administration of superovulation preparations (Moor et al. 1985) act on adrenergic receptors and influence both the levels and metabolism of catecholamines in the central and peripheral adrenergic systems (Fernandez-Pardal et al. 1986; Pástorová and Várady 1996ab).

The median eminence (ME), which connects the hypothalamus with the pituitary gland, is a place where the nerve signals sent from the brain to the blood are integrated. Dopaminergic and noradrenergic nervous endings are located throughout the median eminence, reaching a higher concentration in the palisade zone and the subependymal region of the ME (Zoli et al. 1986). The studies of dopamine turnover in the eminentia mediana indicate that the feedback effect of oestrogens of the secretion of LH takes place in the lateral palisade zone by means of dopaminergic nervous paths (Gallo 1984).

In our study we observed significantly different changes from the control in the concentrations of dopamine in the median eminence after the administration of $\mathrm{FSH}$, although the concentrations of norepinephrine and epinephrine exhibited a significant increase ( $p<0.01$ and $p<0.05$, respectively) in the region. High levels of oestrogens observed after the administration of hormonal preparations (Arita and Kimura 1981) increase the turnover of catecholamines, while progesterone inhibits the activity of tyrosine- $\beta$-hydroxylase, the limiting enzyme of biosynthesis of catecholamines (Arita and Kimura 1981; Rasmussen 1986). Supposedly the increased level of oestrogens affects the increase in the levels of catecholamines, norepinephrine and epinephrine in the median eminence of sheep by means of a feedback mechanism. The turnover and actual levels of catecholamines in the nervous tissue depend on several factors, such as the synthesis and degradation, storage and uptake, transneural flux and interactions with autoreceptors. Alterations in some of these factors with hyperoestrogenisation lead to changes in the concentration and function of catecholamines in the nervous tissue. 
The administration of hormonal preparations carried out in our study resulted in a significant increase of norepinephrine and epinephrine. We thus propose that the given changes in the levels of catecholamines in the median eminence of sheep after the administration of PMSG or FSH are related to steroid alterations after hormonal stimulation.

\section{Obsah katecholamínov v eminentia medialis oviec po superovulácii}

Vplyv hormonálnej superovulácie FSH (450 IU) alebo PMSG (1500 IU) na hladiny katecholamínov (dopamínu, norepinefrínu a epinefrínu) v eminentia medialis oviec sme študovali v estrickom období rádioenzymatickou metódou.

Aplikácia FSH spôsobuje signifikantný vzostup hladín norepinefrínu a epinefrínu v eminentia mediana oviec $(p<0.05 ; p<0.01)$. Pri porovnaní vplyvu použitých hormonálnych preparátov v porovnaní s PMSG na zmeny hladín katecholamínov v našom experimente sa javí, že vplyv FSH je výraznejší v oblasti eminentia medialis oviec.

\section{Aknowledgements}

This project was supported by the Slovak Grant Agency VEGA 1/2446/05.

\section{References}

ARITA J, KIMURA F 1981: Estimation of in vitro activity of tuberoinfundibular dopoaminergic neurons by measurement of DOPA - synthesis in median eminence of hypothalamic slices. Neuroendocrinology 39: 524-529

DEAVER DR, DAILEY M 1983: Effect of ovarian secretion and dopamine secretion of luteinizing hormone and prolaction in ewes. J Anim Sci 57: 978-984

DRIANCOURT MA, FRY RC 1992: Effect of superovulation with FSH or PMSG on growth and maturation of the ovulatory follicles in sheep. Anim Reprod Sci 27: 279-292

FERNANDEZ-PARDAL J, GIMERA WP, GIMERA AL 1986: Catecholamine in cow graafian follicles at proestrus and at diestrus. Biol Reprod 34: 439-445

GALLO RW 1984: Further studies on norepinephrine induced suppression of pulsative luteinizing hormone release in ovariectomized rats. Neuroendocrinology 32: 120-125

CHEVILLARD C, BARDEN N, SAAVEDRA JM 1981: Estradiol treatment decreases type A and increases type B monoamine oxidase in specific brain stem areas and cerebellum of ovariectomized rats. Brain Res 222: 177-181

OHNSON GA, KUPIECKI RM, BAKER CA 1980: Single isotope derivate radioenzymatic methods in the measurement of catecholamines. Metabolism 29: 1106-1113

OWRY O, ROSENBROUGHT N, EARR A, RANDALL R 1951: Protein measurement with the folin phenol reagent. J Biol Chem 194: 265-275

MOOR RM, OSBORN JC, CROSBY IM 1985: Gonadotrophin-induced abnormalities in sheep oocytes after superovulation. J Reprod Fertil 74: 167-172

PÁSTOROVÁ B, VÁRADY J 1992: Plasma catecholamine levels in sheep during superovulation. Vet Med (Praha) 37: 101-107

PÁSTOROVÁ B, VÁRADY J 1996a: The effect of hormonal superovulatory preparation FSH on the levels of catecholamines in the blood plasma of sheep. Physiol Res 45: 125-129

PÁSTOROVÁ B, VÁRADY J 1996b: Catecholamine levels and activity of monoamine oxidase in some hypothalamic structures and in the pineal gland of sheep after administration of FSH. Physiol Res 45: $131-136$

RASMUSSEN DD 1986: New concepts in the regulation of hypothalamic gonadotrophin releasing hormone (GnRH) secretion. J Endocrinol Invest 9: 427-437

SAAVEDRA JM, PALKOVITZ M, DIZER JS, BROWNSTEIN M, ZIVIN JA 1975: Distribution of biogenic amines and related enzymes in the rat pituitary gland. J Neurochem 25: 257-260

SCHIEWE MC, FITZ TA, BROWN JL, STUART LD, WILD DE 1991: Relationship of oestrus synchronization method, circulating hormones, luteinizing hormone and prostaglandin $\mathrm{F}_{2}$ receptors and luteal progesterone concentration to premature luteal regression in superovulated sheep. J Reprod Fert 93: 19-30

ZOLI M, AGNATI LF, FUXE RUGGER M, GARANI G, TOFFAAV G 1986: Neurotransmitter system in the central organization of reproduction. In: Immunocytochemistry J.M. Polak, Van Korpes (Eds), Wright Bristol, pp. 239-249 